研究

\title{
リチウムマンガンスピネル酸化物 $\mathrm{Li}_{4} \mathrm{Mn}_{5} \mathrm{O}_{12}$ の合成
}

\author{
捤山 亮尚, 吉田 高行, 中村 龍哉 \\ 戸田工業侏創造部，テ 739-0652 大竹市明治新開 1-4.
}

\section{Synthesis of Lithium Manganese Spinel Oxide $\mathrm{Li}_{4} \mathrm{Mn}_{5} \mathrm{O}_{12}$}

\author{
Akihisa Kajiyama, Takayuki Yoshida and Tatsuya Nakamura \\ R\&D div., Toda Kogyo Corp., 1-4 Meiji-shinkai, Ohtake 739-0652.
}

Received June 19, 2000

\begin{abstract}
SYNOPSIS
$\mathrm{Li}_{4} \mathrm{Mn}_{5} \mathrm{O}_{12}$ particles were prepared by calcination of $\mathrm{Li}$-hydroxide monohydrate and $\gamma-\mathrm{Mn}_{2} \mathrm{O}_{3}$, which was synthesized by the thermal decomposition of Mn-oxalate, at temperature from 400 to $750^{\circ} \mathrm{C}$ in static air or oxygen atmosphere. The lattice constant varied with the preparation conditions: in the same atmosphere, the lattice constant increased with the calcination temperature, and in the fixed preparation temperature, the calcination in oxygen atmosphere brought smaller lattice constant than that in static air. Additionally, the specimen prepared at lower calcination temperature exhibited higher electrochemical capacity in $3 \mathrm{~V}$ region with better cycle performance. These variations are related to the average $\mathrm{Mn}$ valence state, and higher valence state of $\mathrm{Mn}$ is required for high perfromance of $\mathrm{Li}_{4} \mathrm{Mn}_{5} \mathrm{O}_{12}$ as $3 \mathrm{~V}$ cathode material. The low-temperature synthesis is thought to be suitable for them.
\end{abstract}

KEY WORDS

Li-Mn spinel oxide, $\gamma-\mathrm{Mn}_{2} \mathrm{O}_{3}$, lattice constant, electrochemical capacity

\section{1 緒 言}

エネルギー密度の高い $\mathrm{Li}$ イオン二次電池の正極材料とし て,リチウム含有遷移金属酸化物の材料開発が積極的に進め られている1-わ.なかでも，コバルトやニッケルと比べて原料 が豊富に存在する安価なマンガンを用いることから， Li-Mn スピネル酸化物が注目されている。この Li-Mnスピネル酸化 物では, Li 或いは Mnの金属イオンの欠損，さらには格子酸 素の欠損等の存在が知られており, 非化学量諭性の極めて大 きな化合物である ${ }^{8-13}$. これらの非化学量論性, 欠宿棈造は, その電気化学特性に敏感に反映されるものであると同時に， 作成条件によって大きく左右されるものである.このような 観点から，我々は，特にマンガン酸化物原料に注目して，4V 級の正極材料である正規組成 $\mathrm{LiMn}_{2} \mathrm{O}_{4}$ に近い組成の Li-Mn ス ヒネル酸化物の合成を行ってきた. その結果, 葆酸マンガン を熱分解して作成したマンガン酸化物 (正確には $\mathrm{Mn}_{3} \mathrm{O}_{4}$ と $\gamma$ $\mathrm{Mn}_{2} \mathrm{O}_{3}$ の中間の組成であるが，ここでは $\gamma-\mathrm{Mn}_{2} \mathrm{O}_{3}$ と記述する ことにする)加 $\mathrm{Li}$ 化合物と非常によく反応することを見い出 した ${ }^{14}$. 今回は, この反応性の良い藤酸マンガンを熱分解し
て作成した $\gamma-\mathrm{Mn}_{2} \mathrm{O}_{3}$ を用いて, 3 級の正極材料として作動す る Li-Mnスビネル酸化物の端組成のひとつである $\mathrm{Li}_{4} \mathrm{Mn}_{5} \mathrm{O}_{12}$ の 合成とその電気化学特性について調べた.

\section{2 実験方法}

硫酸マンガン(試薬特級)の水溶液に，機械的摚汼下で等モ ル以上の葆酸の水溶液を加えて葆酸マンガンの沈澱を作成し た.この沈激物を漟別・水洗・乾燥させた後， $450^{\circ} \mathrm{C}$ の温度で 空気中にて熱分解させることで $\gamma-\mathrm{Mn}_{2} \mathrm{O}_{3}$ 粓子粉末を得た.こ の得られた $\gamma-\mathrm{Mn}_{2} \mathrm{O}_{3}$ 粒子粉末と水酸化りチウム一水和物(試独 特級)をモル比で， $\mathrm{L} / \mathrm{M} \mathrm{M}=4 / 5$ となるように自動乳鉢を用いて 十分に混合した.この混合粉末を，500 $\mathrm{kg} / \mathrm{cm}^{2}$ にて圧密成形 し, 空気中或いは酸素気流中にて, 400 750 $\mathrm{C}$ の温度にて 10 時間加熱・狫成し，その後，炉冷することでサンプルを作成 した.

生成相は粉末 X線回折により同定し，格子定数を NelsonRiley法によって決定した. 焼成物の破断面を走查型電子䫓微 鏡にて観察した。 また, 得られた Li-Mn スビネル酸化物の一 
部を酸に浴解し，プラスマ分光法および原子吸光法にて， Li/ $\mathrm{Mn}$ の元素比を決定した. また, 試料の一部を過剩量の $\mathrm{VOSO}_{4}-\mathrm{H}_{2} \mathrm{SO}_{4}$ 水溶液に溶解した. この時にすべてのマンガン

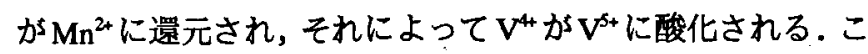
の酸化されずに残った $\mathrm{V}^{4}$ の量を $\mathrm{KMnO4}$ で滴定することで， 酸化された $V^{4}$ 量を決定し,マンガンの平均価数を算出した 9. さらには, 得られた Li-Mn スピネル酸化物の電気化学特性 を調へるために, Li-Mn スピネル酸化物粉末:アセチレンフ ラック:PTFE $=6: 3: 1$ の重量比の混合物で正極を作成し，金 属 Liを負極, プロピレンカルボネート/ジメトキシエタンの 混合溶液 (重量比で 1/1) に, 電解質 $\mathrm{LiClO} 4$ を $1.0 \mathrm{M}$ の濃度で溶 解したものを電解液として用い，室温にて定電流で充放電特 性の測定を行った. その際, 充電上限電圧, 放電下限電圧を それぞれ $3.2 \mathrm{~V}$ と $2.2 \mathrm{~V}$ とした。

\section{3 実験結果及び考突}

粉末 $\mathrm{X}$ 線回折の結果, 空気中, 酸素気流中，いずれの場合 においても， $\gamma-\mathrm{Mn}_{2} \mathrm{O}_{3}$ 粒子粉末と水酸化义チウムは十分に反応 し，400Cという低温であるにもかかわらず，ほぼ単相のリチ ウムマンガンスピネル酸化物が得られた.ところで,一方, 水 溶液中で硫酸マンガンを水酸化アルカリで中和し，この愁濁 液に空気を通気することによっても, $\gamma-\mathrm{Mn}_{2} \mathrm{O}_{3}$ の微粒子粉末か 得られるのであるが, この $\gamma-\mathrm{Mn}_{2} \mathrm{O}_{3}$ をマンガン酸化物原料と して用いて同様に水酸化リチウムと反応させた場合, 未反応 のマンガン酸化物が一部残存し, 単相のリチウムマンガンス ピネル酸化物は得られなかった.これらの事実は, マンガン 酸化物原料として用いた葆酸マンガンを熱分解して作成した $\gamma-\mathrm{Mn}_{2} \mathrm{O}_{3}$ の反応性の良さを表しているものと考えられる。この 反応性の良さは, 粒子粉末の粒度だけではなく, 純度(特にア ルカリ金属イオン,アルカリ土類金属イオンなどの不純物)に も起因しているものと思われるか，現在のところ, その詳細 は不明である.

空気中で焼成を行った場合，600 $\mathrm{C}$ 以下では粉末 $\mathrm{X}$ 線回折 から判断する限りにおいては単相のリチウムマンガンスピネ ル酸化物が得られるが, 焼成温度が高くなり $600^{\circ} \mathrm{C}$ を越える と, リチウムマンガンスビネル酸化物以外に不純物相として $\mathrm{Li}_{2} \mathrm{MnO}_{3}$ が混在した.一方, 酸素気流中で焼成を行った場合で は, $700^{\circ} \mathrm{C}$ 以下では粉末 $\mathrm{X}$ 線回折から判断する限りにおいて は単相のリチウムマンガンスビネル酸化物が得られ，焼成温 度が $700^{\circ} \mathrm{Cを}$ 越えると，リチウムマンガンスビネル酸化物以 外に不純物相として $\mathrm{Li}_{2} \mathrm{MnO}_{3}$ 加現れた。

これらの得られたリチウムマンガンスビネル酸化物の格子 定数は一定ではなく，焼成温度及び佬成雾囲気により大きく 変化した. 焼成温度及び焼成雾囲気の違いによる格子定数の 変化の様子を Fig.1に示した. 同一の焼成雾囲気においては, 焼成温度が高くなるほど格子定数は大きくなる傾向にあるこ とが認められた。 また, 焼成温度が同じである場合, 架気中 で焼成したものの方が, 酸素気流中での焼成のものよりも大 きな格子定数を示すことがわかる.
以上の $\mathrm{Li}_{2} \mathrm{MnO}_{3}$ 不純物相の出現及ひ焼成条件による格子定 数の変化については, 以下のように考えることができる.リ チウムマンガンスピネル酸化物は, 三つの端組成, $\mathrm{LiMn}_{2} \mathrm{O}_{4}$, $\mathrm{Li}_{2} \mathrm{Mn}_{4} \mathrm{O}_{9}$, 及び, $\mathrm{Li}_{4} \mathrm{Mn}_{5} \mathrm{O}_{12}$ で表される固溶体を形成する ${ }^{8.9}$. 本研究で問題にしている端組成の一つである $\mathrm{Li}_{4} \mathrm{Mn}_{5} \mathrm{O}_{12}$ の合成 を検討する際にも，この固溶体の存在を考虑しなければなら ない. 以前に $4 \mathrm{~V}$ 級の正極材料である正規組成 $\mathrm{LiMn}_{2} \mathrm{O}_{4}$ に近い 組成の Li-Mn スピネル酸化物の合成の際にも，焼成温度に よって格子定数が変化する現象が見られだ)。この場合は, 低 温ではカチオンが欠損したリチウムマンガンスビネル酸化物 が生成しており，温度が高くなるほどカチオン欠損か減少 し非化学量論性が小さくなり，正規組成に近づくことによる ものであった.すなわち, $\mathrm{LiMn}_{2} \mathrm{O}_{4}$ と $\mathrm{Li}_{2} \mathrm{Mn}_{4} \mathrm{O}_{9}$ の間の固溶体 が生成しているためであり,これらの非化学量論性は, 焼成 中の酸素ポテンシャルの変化に起因し, 高温になるほど酸素 ポテンシャルが減少, このため生成するリチウムマンガンス ピネル酸化物中のマンガンの平均価数が低下することが原因

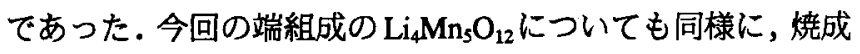
中の酸素ポテンシャルの影響を考えると，焼成温度が高くな る或いは焼成雾囲気が酸素気流中から空気中に変化すると, 生成すべきリチウムマンガンスピネル酸化物, $\mathrm{Li}_{4} \mathrm{Mn}_{5} \mathrm{O}_{12}$ 中の マンガンの平均価数が低下し, 以下のような分解反応が起こ るものと考えられる。

$$
\begin{aligned}
(1+1 / 2 \mathrm{X}) & \mathrm{Li}_{4} \mathrm{Mn}_{5} \mathrm{O}_{12} \\
& \rightarrow \mathrm{Li}_{4-\mathrm{X}} \mathrm{Mn}_{5 \times \mathrm{X}} \mathrm{O}_{12}+3 / 2 \mathrm{XLi}_{2} \mathrm{MnO}_{3}+3 / 4 \mathrm{XO}_{2}
\end{aligned}
$$

$\mathrm{Li}_{4} \mathrm{Mn}_{5} \mathrm{O}_{12}$ の分解反応によって新たに生成した $\mathrm{Li}_{4 \times} \mathrm{Mn}_{5+\mathrm{x}} \mathrm{O}_{12}$ は, $\mathrm{LiMn}_{2} \mathrm{O}_{4}$ と $\mathrm{Li}_{4} \mathrm{Mn}_{5} \mathrm{O}_{12}$ の間の固溶体であり，マンガンの平 均価数が低いものである. 平均洒数が低いものほどマンガン

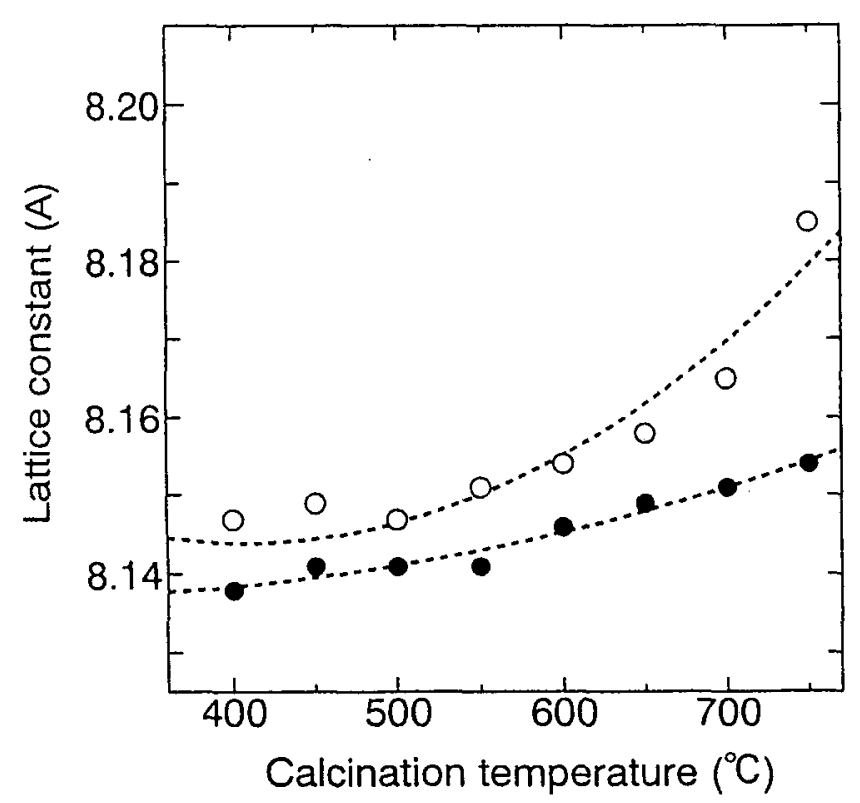

Fig.1 Variation of lattice constant with the calcination temperature: in static air (open circle) and in oxygen flow (closed circle). 
Table 1 The average $\mathrm{Mn}$ valence versus the calcination conditions (temperature and atmosphere).

\begin{tabular}{|c|c|c|}
\hline $\begin{array}{c}\text { Calcination temperature } \\
\left({ }^{\circ} \mathrm{C}\right)\end{array}$ & $\begin{array}{c}\text { Average Mn valence } \\
\text { (calcined in static air })\end{array}$ & $\begin{array}{c}\text { Average Mn valence } \\
\text { (calcined in oxygen flow) }\end{array}$ \\
\hline 400 & 3.92 & 3.97 \\
\hline 450 & 3.84 & 3.90 \\
\hline 500 & 3.81 & 3.86 \\
\hline 600 & 3.77 & 3.86 \\
\hline 700 & 3.69 & 3.77 \\
\hline
\end{tabular}

イオンのイオン半径が大きいため，この新たに生成したりチ ウムマンガンスヒネル酸化物, $\mathrm{Li}_{4} \times \mathrm{Mn}_{5 \times \times} \mathrm{O}_{12}$ は大きな格子定 数を示す。これは, Fig.1に示した実験結果と一致している. 組成分析からのマンガン平均洒数を求めた結果をTable1 に示 す. ところで，空気中 $600^{\circ} \mathrm{C}$ 以上で作製された試料において は，不純物相として混在している $\mathrm{Li}_{2} \mathrm{MnO}_{3}$ をも含めた測定で ある.この表からもわかるように, マンガンの平均価数は, 焼 成雾囲気が一定の場合，焼成温度が高いほど低くなっている。 また，マンガンの平均価数は，焼成温度が同一の場合，焼成 時の雾囲気が酸素リッチであるほど高くなっていることがわ かる.この結果は, 格子定数の焼成条件による変化とよく対 応しており，式(1)のリチウムマンガンスビネル酸化物の分解 反応が起こっていることを支持している.ところで一方，不 純物相である $\mathrm{Li}_{2} \mathrm{MnO}_{3}$ の存在に関しては, 粉末 $\mathrm{X}$ 線回折の測 定の感度との兼ね合いがあり，低温では(1)の分解反応がわず かにしか進行せず, $\mathrm{Li}_{2} \mathrm{MnO}_{3}$ の含有率が測定感度以下であった

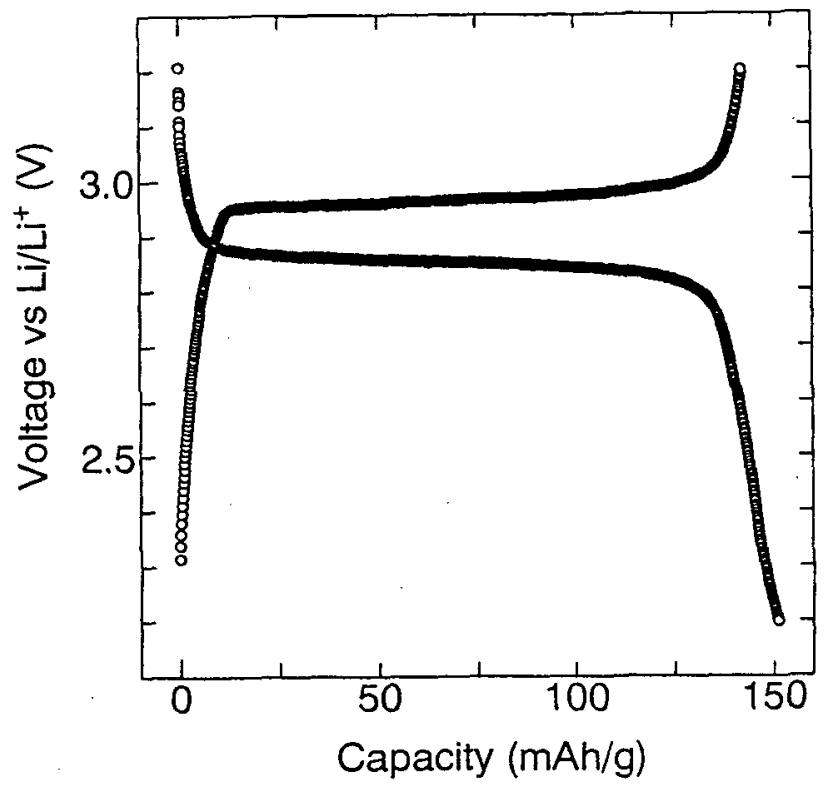

Fig.2 The charging and discharging curve of $\mathrm{Li}_{4} \mathrm{Mn}_{5} \mathrm{O}_{12}$ cathode using the specimen synthesized at $400^{\circ} \mathrm{C}$ under oxygen flow: the charge-discharge rate of approximately $\mathrm{C} / 8$.
ため，検出できなかったものと考えられる．後に述べる電気 化学特性の結果と併せて, 酸素気流中, $400 \sim 500^{\circ} \mathrm{C}$ の温度範 囲での焼成においては, $\mathrm{Li}_{4} \mathrm{Mn}_{5} \mathrm{O}_{12}$ 単一相加得られたものと考 えられる。

これらの焼成温度, 焼成雾囲気による生成物の変化は, こ れらの材料を用いた正極の充放電特性にも大きく影響した。 $400^{\circ} \mathrm{C}$,酸素気流中で作成したリチウムマンガンスビネル酸化 物 $\mathrm{Li}_{4} \mathrm{Mn}_{5} \mathrm{O}_{12}$ の充放電曲線を Fig. 2 に示す. 充放電反応は, $3 \mathrm{~V}$ 付近の極めて狭い電圧範囲でのみ行われる，典型的な二相反 応であることがわかる.Fig.3に空気中での焼成のものについ て，初期放電容量と焼成温度との関係を示した．また，Fig.4 には酸素気流中での焼成のものについて，同様に初期放電容 量と焼成温度との関係を示した。初期の放電容量は，空気中 での焼成のもの，酸素気流中での燒成のものどちらにおいて も，佬成温度が高くなるほど小さくなった．また，焼成温度 が同じである場合は，初期の放電容量は，空気中で焼成した

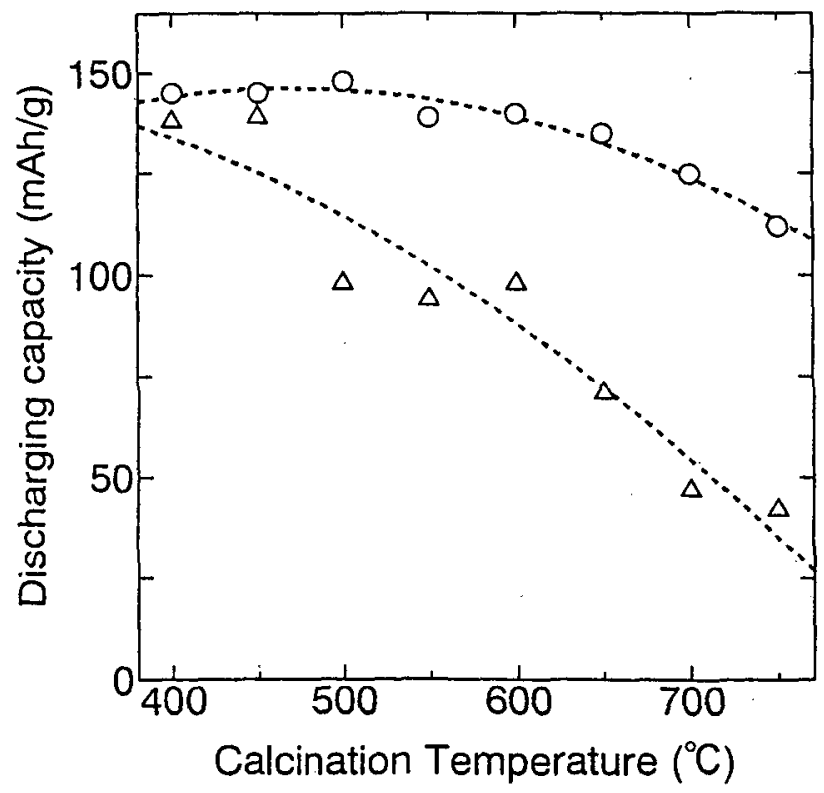

Fig.3 The discharge capacity versus the calcination temperature in static air atmosphere: open circles and triangles denotes the capacities of 1 st and 5th cycle, respectively. 
ものよりも，酸素気流中で焼成したものの方が大きくなった． 初期放電容量は，リチウムマンガンスピネル酸化物中にリチ ウムイオンが挿入される(リチウムイオンが空であった16c八 面体サイトに挿入され，同時にその㨂入サイトに近接した $8 \mathrm{a}$ 四面体サイトに存在していたリチウムイオンが，もう一つの 隣接した16c八面体サイトに移動するものと考えられる)こと に伴って，四価のマンガンイオンが三価に買元される反応に 対応している.このことから、リチウムマンガンスピネル酸 化物中のマンガンの価数が高いものほど，大きな初期放電容 量が得られる.すなわち，低温，酸素気流中で焼成されたも のほど，初期放電容量が大きくなったのである.

これらの焼成温度, 焼成䨌囲気の違いによる生成相の充放 電特性への影響をまとめ, 生成相の格子定数と放電容量の関 係として Fig.5に示した. 図中には，サイクル特性の目安とし て, 5 回目の充放電サイクルにおける放電容量も併せて示し た. 格子定数の小さいものほど，初期放電容量が大きいのは 既に述べたとおりであるが，さらにはこれら格子定数の小さ いものほど，サイクル特性も良好であることが確認された。 正規組成のリチウムマンガンスビネル酸化物 $\mathrm{LiMn}_{2} \mathrm{O}_{4}$ におい ては，通常は $4 \mathrm{~V}$ 付近で生じる $\mathrm{Li}_{6} \mathrm{Mn}_{2} \mathrm{O}_{4}(\delta=0.0 \sim 1.0)$ の範囲 のリチウムの電気化学的な挿脱入反応が問題にされているが, $3 \mathrm{~V}$ 付近で $\mathrm{Li}_{8} \mathrm{Mn}_{2} \mathrm{O}_{4}(\delta=1.0 \sim 2.0)$ のリチウムの電気化学的挿 脱入反応も生じることが知られている.この3V付近での電気 化学的反応は, マンガンの還元反応 ( マンガンの平均価数が 3.5 価から三価)を伴っている.よく知られているように酸素 八面体配位にあるマンガンの三価はヤーンテラーイオンであ り，周りの酸素の配位を正八面体加大きく昰ませることで その電子軌道エネルギーを安定化させる。このため, 3V付近 で $\mathrm{Li}_{8} \mathrm{Mn}_{2} \mathrm{O}_{4}(\delta=1.0 \sim 2.0)$ のリチウムの電気化学的择脱入反応

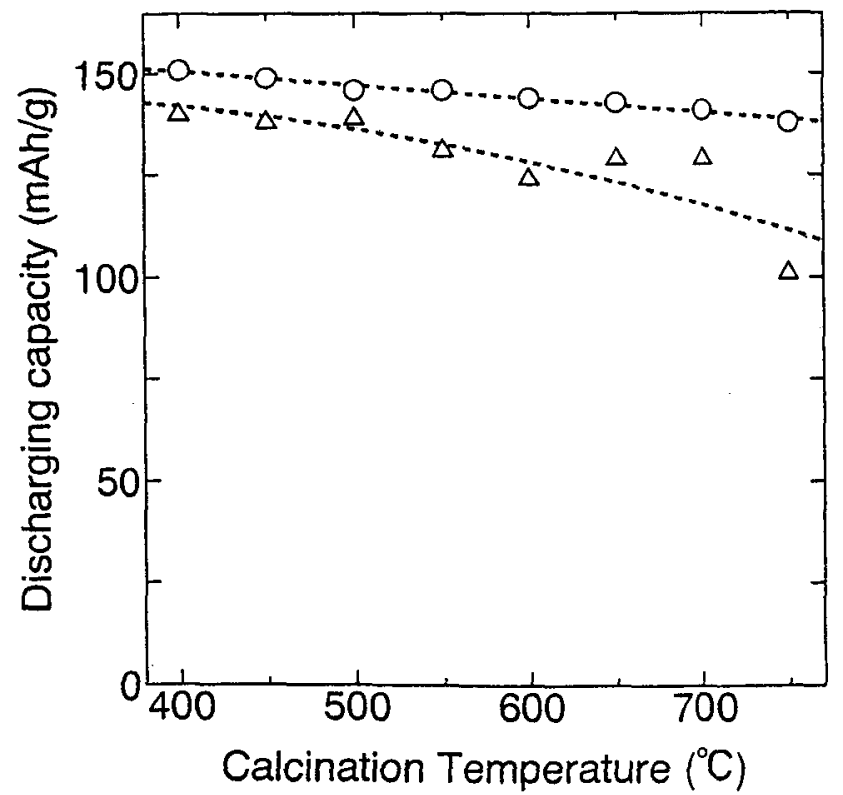

Fig.4 The discharge capacity versus the calcination temperature in oxygen flow atmosphere: open circles and triangles denotes the capacities of $1 \mathrm{st}$ and 5 th cycle, respectively.
には, 非常に大きなスピネル格子の変形を伴う。このため, 3Vでの充放電反忘では，その可逆性が劣化し，良好なサイク ル特性が得られない。この正規組成のリチウムマンガンスピ ネル酸化物 $\mathrm{LiMn}_{2} \mathrm{O}_{4}$ との類推から， $\mathrm{Li}_{4} \times \mathrm{Mn}_{5+\mathrm{x}} \mathrm{O}_{12}$ の $3 \mathrm{~V}$ 領域で の充放電サイクルの特性劣化には，ヤーンテラー効果か関与 していることが考えられる.初期状態において，マンガンの 価数が低くなっている，すなわち Xが大きく，格子定数の大 きいものほど，放電の末期に三価のマンガンイオンが增加す るため，大きな格子変形を起こしやすく，そのため，サイク ル可逆性が低下するものと考えている.

以上から，格子定数が小さく，マンガンの価数ができる限 り四価に近いもの，すなわち，端組成 $\mathrm{Li}_{4} \mathrm{Mn}_{5} \mathrm{O}_{12}$ に近いリチウ ムマンガンスピネル酸化物ほど, 3V領域で大きな初期放電容 量を有しており，しかも，良好なサイクル特性を示すもので あることがわかった. またこのような端組成 $\mathrm{Li}_{4} \mathrm{Mn}_{5} \mathrm{O}_{12} に$ に近 いリチウムマンガンスピネル酸化物を作成するに関しては, 酸素ポテンシャルの高い条件である酸素気流中で, しかも, 可能な限り低温で合成することが好ましいことがわかった。 低温合成のためには, 反応性の高いマンガン酸化物原料を用 いることが重要であり，この意味から本研究で採用した葆酸 マンガンの熱分解にて作成した $\gamma-\mathrm{Mn}_{2} \mathrm{O}_{3}$ が有用であることが 示唆された.

\section{4 結言}

莑酸マンガンの熱分解にて作成した $\gamma-\mathrm{Mn}_{2} \mathrm{O}_{3}$ を用いて，リ チウムマンガンスピネル酸化物 $\mathrm{Li}_{4} \mathrm{Mn}_{5} \mathrm{O}_{12}$ の合成を検討した.

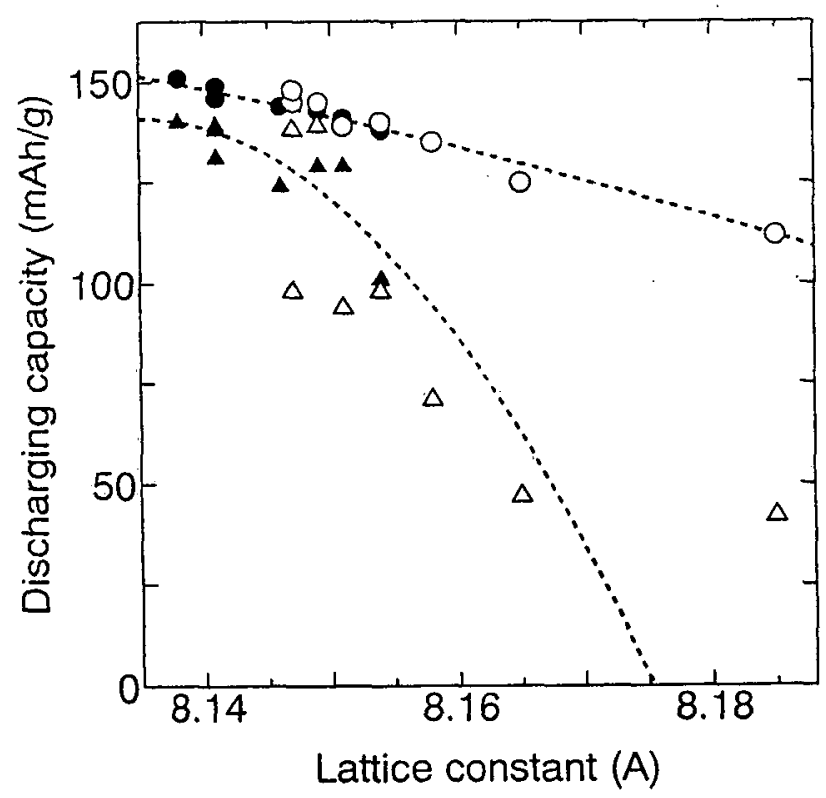

Fig.5 The relationship between the discharge capacity and the lattice constant: open circles and triangles denotes the capacities of 1st and 5th cycle for the specimen prepared in static air, respectively. Closed circles and triangles denotes the capacities of 1 st and 5 th cycle for the specimen synthesized under oxygen flow, respectively. 
(1) 得られたリチウムマンガンスビネル酸化物の格子定数は, 焼成温度, 焼成雾囲気により变化した. 高温で酸素ポテン シャルの低いものほど格子定数は大きくなった。

(2) 格子定数の小さなリチウムマンガンスビネル酸化物を用い るほど, $3 \mathrm{~V}$ 領域で大きな放電容量及ひ良好な充放電サイ クル特性が得られた。

(3) $3 \mathrm{~V}$ 用の正極材料であるリチウムマンガンスビネル酸化物 $\mathrm{Li}_{4} \mathrm{Mn}_{5} \mathrm{O}_{12}$ を得るためには，低温，高酸素分圧下での合成 が適している、反応性の高いマンガン酸化物原料である， 葆酸マンガンの熱分解にて作成された $\gamma-\mathrm{Mn}_{2} \mathrm{O}_{3}$ を用いるこ との有用性が確認された。

\section{文献}

1) K.Mizushima, P.C.Jones, P.J.Wisemann and J.B.Goodenough: " $\mathrm{Li}_{2} \mathrm{CoO}_{2}(0<\mathrm{z}<1)$ : A New Cathode Material for Batteries of High Energy Density", Mater. Res. Bull., 15(1980)783-789.

2) M.Broussely, F.Perton, J.Labat, R.J.Staniewicz and A.Romero: " $\mathrm{Li} / \mathrm{Li}_{x} \mathrm{NiO}_{2}$ and $\mathrm{Li} / \mathrm{Li}_{x} \mathrm{CoO}_{2}$ Rechargeable Systems: Comparative Study and Performance of Practical Cells", J. Power Sources, 43-44(1993)209-216.

3) P.G.Bruce, A.Lisowska-Oleisiak, M.I.Saidi and C.Vincent: "Vacancy Diffusion in the Intercalation Electrode $\mathrm{Li}_{1-\mathrm{x}} \mathrm{NiO}_{2}$ ", Solid State Ionics, 57(1992)353-358.

4) J.M.Tarascon, W.R.McKinnon, F.Coowar, T.N.Browmer, G.Amatucci and D.Guyomard: "Synthesis Conditions and Oxygen Stoichiometry Effects on Li Insertion into the Spinel $\mathrm{LiMn}_{2} \mathrm{O}_{4}$ ", J. Electrochem. Soc., 141(1994)1421-1431.

5) A.Rougier, I.Saadoune, P.Gravereau, P.William and C.Delmas: "Effects of Cobalt Substitution on Cationic Distribution in $\mathrm{LiNi}_{1-\mathrm{y}} \mathrm{Co}_{\mathrm{y}} \mathrm{O}_{2}$ Electrode Materials", Solid State Ionics, 90(1996) 83-90.

6) P.Barboux, J.M.Tarascon and F.K.Shokoohi: "The Uses of
Acetates as Precursors for the Low-Temperature Synthesis of $\mathrm{LiMn}_{2} \mathrm{O}_{4}$ and $\mathrm{LiCoO}_{2}$ Intercalation Compounds", J. Solid State Chem., 94(1991)185-196.

7) Y.Xia, H.Takeshige, H.Noguchi and M.Yoshio: "Studies on an Li-Mn-O Spinel System (obtained by melt-impregnation) as a Cathode for 4V Lithium Batteries: Part 1. Synthesis and Electrochemical Behaviour of $\mathrm{Li}_{\mathbf{z}} \mathrm{Mn}_{2} \mathrm{O}_{4}{ }^{\prime \prime}$, J. Power Sources, 56 (1995)61-67.

8) M.M.Thackeray, M.F.Mansuetto, D.W.Dees and D.R.Visser: "The Thermal Stability of Lithium-Manganese Oxide Spinel Phases", Mater. Res. Bull, 31(1996)133-140.

9) C.Masquelier, M.Tabuchi, K.Ado, R.Kanno, Y.Kobayashi, Y.Maki, O.Nakamura and J.B.Goodenough: "Chemical and Magnetic Characterization of Spinel Materials in the $\mathrm{LiMn}_{2} \mathrm{O}_{4}$ $\mathrm{Li}_{2} \mathrm{Mn}_{4} \mathrm{O}_{9}-\mathrm{Li}_{4} \mathrm{Mn}_{5} \mathrm{O}_{12}$ System", J. Solid State Chem., 123(1996) 255-266.

10) Y.Xia and M.Yoshio: "Optimization of Spinel $\mathrm{Li}_{1+x} \mathrm{Mn}_{2-\mathrm{X}} \mathrm{O}_{4}$ as a 4V Li-cell Cathode in terms of a Li-Mn-O Phase Diagram", J. Electrochem. Soc., 144(12) (1997)4186-4194.

11) Y.Gao and J.R.Dunn: "Correlation Between the Growth of the 3.3V Discharge Plateau and Capacity Fading in $\mathrm{Li}_{1+x} \mathrm{Mn}_{2-x} \mathrm{O}_{4}$ Materials", Solid State Ionics, 84(1996)33-40.

12) P.Strobel, F.Le Cras, L.Seguin, M.Anne and J.M.Tarascon: "Oxygen Non-stoichiometry in Li-Mn-O Spinel Oxides: A Powder Neutron Diffraction Study", J. Solid State Chem., 135 (1998)132-139.

13) R.Kanno, A.Kondo, M.Yonemura, R.Gover, Y.Kawamoto, M.Tabuchi, T.Kamiyama, F.Izumi, C.Masquelier and G.Rousse: "The Relationships between Phases and Structures of Lithium Manganese Spinels", J. Power Sources, 81-82(1999)542-546.

14) T.Nakamura and A.Kajiyama: "Synthesis of Li-Mn Spinel Oxide using $\mathrm{Mn}_{2} \mathrm{O}_{3}$ Particles", Solid State Ionics, 124(1999)45-52. 